\title{
ARTIFICIAL FLOODS IN RESIDUAL FLOW REACHES - HOW DO THEY AFFECT HYDRAULIC HABITATS?
}

\author{
SEVERIN STÄHLY \\ Laboratoire de Constructions Hydrauliques (LCH), École Polytechnique Fédérale de Lausanne (EPFL), Lausanne, Switzerland \\ e-mail : severin.staehly@epfl.ch
}

\begin{abstract}
Floodplains in hydropower-controlled rivers, where a constant residual flow discharge is imposed, often lack sediment supply and periodic inundation due to the absence of natural flood events. In this study we compare two residual flow systems. The first river is the Spöl, located in the Swiss National Park close to the boarder with Italy. Since the year 2000, artificial floods are released from the Ova Spin Dam on a yearly bases, with the aim to restore river dynamics and habitats. The second river, is the Sarine in Western Switzerland where an artificial flood was released from the Rossens Dam for the first time. At one location this flood event was combined with sediment replenishment. In this study, an analysis of the two different systems before and after the event using the Hydro-Morphological Index of Diversity (HMID) is presented. The index is based on the variability of flow depth and flow velocity and represents the habitat diversity on a reach scale. Results reveal that a flood pulse can significantly increase hydraulic habitat diversity in a river reach and that sediment availability is crucial. Nevertheless, the change in habitats of a single flood event has a minor effect if artificial floods are periodically released. Under such conditions, the river has already reached an equilibrium condition considering habitat diversity.
\end{abstract}

Keywords: e-flows, hydropower, river restoration, hydro-morphological index of diversity, hydraulic habitats

\section{INTRODUCTION}

Flow and sediment regimes can induce a large variety of habitats to rivers (Allan \& Castillo, 2007; Wohl et al., 2015). Hydro-morphological conditions are an essential factor for in-stream life. Species have preferred ecohydraulic conditions, including flow depths, velocities and shear stresses near the streambed (Heggenes, 1996; Statzner et al., 1988). The natural flow regime as well as the temporal and spatial ecohydraulic diversity are often altered by the construction of dams (Moyle \& Mount, 2007). Dams trap sediment in the upstream reservoir and interrupt the sediment continuum, what can cause severe deficits in the downstream river segment (Kondolf, 1997; Petts \& Gurnell, 2005).

To counteract these deficits, sediment replenishment combined with the release of artificial flood events have been widely studied (Arnaud et al., 2017; Battisacco et al., 2016; Gaeuman, 2012; Gaeuman et al., 2017; Heckmann et al., 2017; Robinson, 2012; Robinson et al., 2018; Staentzel et al., 2018; Stähly et al., 2018).

In the study presented here, two restoration measures of different time scales are compared. Both study rivers are located in Switzerland. In the Sarine River downstream of Rossens Dam, built in 1948, an artificial flood was released for the first time in fall 2016 (Döring et al., 2018; Stähly et al., 2019). In the Spöl River, an active residual flow river segment management has been applied with periodical flood events since summer 2000.

\section{SITE DESCRIPTION}

\subsection{Sarine River}

The Sarine originates on $2252 \mathrm{~m}$ a.s.l. in Western Switzerland and drains a catchment of $1900 \mathrm{~km}^{2}$. After $126 \mathrm{~km}$ it joins the Aare, a tributary of the Rhine, ending in the Northern Sea. One of the six reservoirs along the main stem of the river is the Rossens Dam close to Fribourg. It creates the $200 \mathrm{Mio} \mathrm{m}^{3}$ large reservoir Lac de la Gruyère (maximum reservoir level on $677 \mathrm{~m}$ a.s.I.). 2.5 to $3.5 \mathrm{~m}^{3} / \mathrm{s}$ released as residual flow to the about $13 \mathrm{~km}$ long river segment between the Rossens Dam and the power house in Hauterive (see Figure 1). This river segment has a bed slope of $0.3 \%$. The Lac de la Gruyère is about $13 \mathrm{~km}$ long, retaining all incoming sediment. Furthermore, spilling during floods has become rare.

\subsection{Spöl River}

The Spöl is a mountain river located on $2252 \mathrm{~m}$ a.s.l. in Eastern Switzerland in the Swiss National Park. It originates on $3031 \mathrm{~m}$ a.s.l. and drains a catchment of $430 \mathrm{~km}^{2}$ before it drains in the Inn River at Zernez (1470 m a.s.I.), a tributary of the Danube ending in the Black Sea. The main reservoir Lago di Livigno (max reservoir level on $1805 \mathrm{~m}$ a.s.l.) with a storage capacity of $164 \mathrm{Mio} \mathrm{m}^{3}$, works as pumped-storage hydropower plant with 
the Lai dad Ova Spin (max reservoir level on $1630 \mathrm{~m}$ a.s.I.) which as a volume of $6.2 \mathrm{Mio}^{3}$. From the Lai dad Ova Spin, water is diverted to the second stage hydropower plant Pradella (1141 m a.s.l.). In the presented research, the river segment below the Ova Spin reservoir was studied. The Ova Spin Dam releases a residual flow of $0.3-0.9 \mathrm{~m}^{3} / \mathrm{s}$ to the remaining $6 \mathrm{~km}$ of the river. About $3.2 \mathrm{~km}$ downstream of the dam, the tributary Ova da Cluozza supplies the Spöl with a significant amount of sediment and a natural flow regime. Therefore two river segments are studied in the Spöl, one upstream (straight reach) and one downstream (braided reach) of the junction (see Figure 2). The upstream segment was ca. 70, the downstream $100 \mathrm{~m}$ long. The bed slopes are about $1.2 \%$ in the upstream and $0.8 \%$ in the downstream segment. Compared to the Sarine, artificial floods are released since June 2000 on a yearly basis from the Ova Spin Dam with the aim to re-active sediment dynamics.

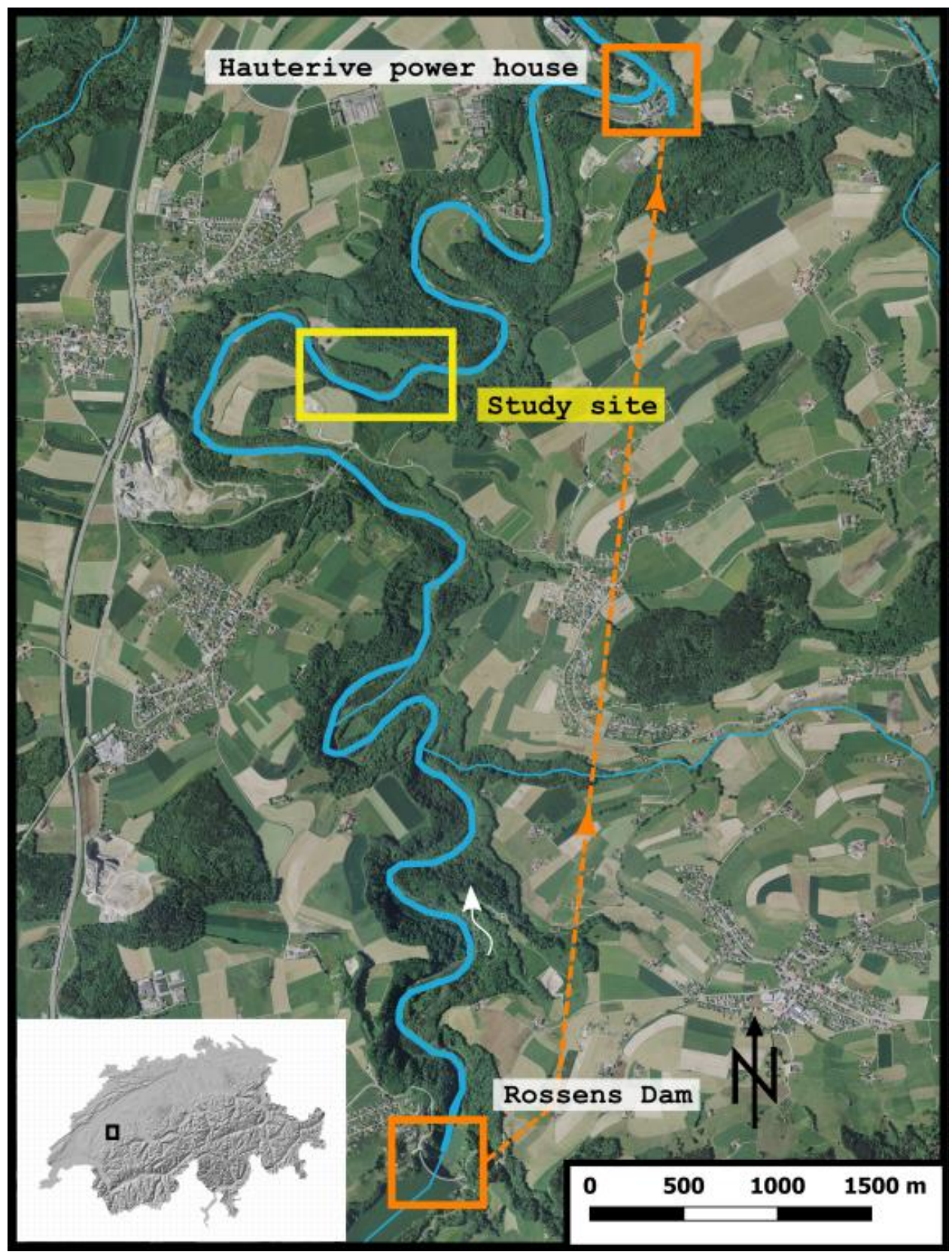

Figure 1. Overview of the residual flow river segment of the Sarine between the Rossens Dam and the power house in Hauterive. 


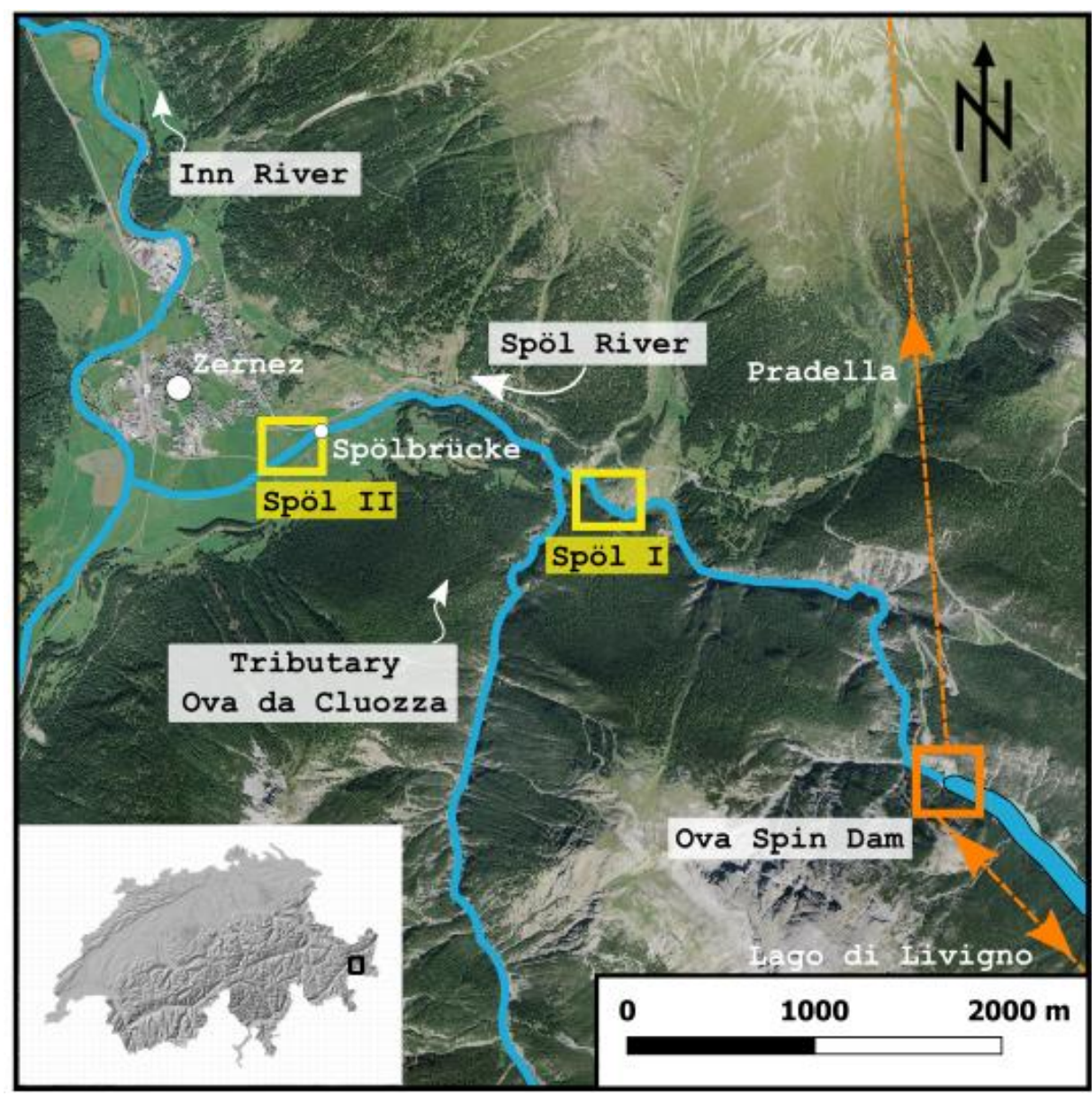

Figure 2. Overview of the Spöl and the two study sites in Eastern Switzerland.

\section{METHODOLOGY}

\subsection{Hydro-morphological index of diversity}

To quantify the change hydraulic habitat diversity, the hydro-morphological index of diversity (HMID) was used. The HMID is an easy applicable quantitative measurement tool for estimating the habitat diversity in rivers, which combines both geomorphological and ecohydraulic conditions (Gostner et al., 2013; Stähly et al., 2019). The basic HMID of a river segment takes into account the spatial distribution of hydraulic measured values of flow depth and flow velocity (Equation 1). It results in a single value, mostly between 1 and 15, representing the hydraulic habitat diversity in the river segment. According to the resulting value, river segments can be classified into low $(\mathrm{HMID}<5)$, medium $(5<\mathrm{HMID}<9)$ or high $(\mathrm{HMID}>9)$ hydraulic habitat variability.

$$
H M I D_{\text {Site }}=\prod_{i}\left(1+C V_{i}\right)^{2}=\left(1+\frac{\sigma_{h}}{\mu_{h}}\right)^{2} \cdot\left(1+\frac{\sigma_{v}}{\mu_{v}}\right)^{2}
$$

where,

$$
\begin{aligned}
& C V=\text { coefficient of variation }[-] \\
& \mu=\text { mean value }[\mathrm{m}] \text { or }\left[\frac{\mathrm{m}}{\mathrm{s}}\right] \\
& \sigma=\text { standard deviation }[\mathrm{m}] \text { or }\left[\frac{\mathrm{m}}{\mathrm{s}}\right]
\end{aligned}
$$

In this belonging, the HMID differs substantially from other hydro-morphological river assessment methods. Most of them include ecological factors and are based on expert judgment and therefore less objective (Barbour et al., 1999; Feio et al., 2016; Rinaldi et al., 2017). The HMID does not give information about the water quality, turbidity or biomass found in the analyzed river segment. It represents the ecohydraulic conditions in the river at the moment of measurement and depends on the discharge. Hence, the HMID is a powerful tool to quantify 
the hydro-morphological effects of river restoration measures, and thus can be used as control of success of realized restoration projects.

\subsection{Sampling procedure}

The data is sampled along regularly spaced cross-sections. The starting point of the cross-sections needs to be chosen correctly to include important hydraulic habitat units such as pools and riffles (Stähly et al., 2019a). The spacing between the datapoints along a cross-section has to be constant to ensure the objectivity of the method. The data requirement depends largely from the complexity of the morphology in a river. In the Sarine River, data was sampled along ten cross-sections, resulting in ca. 200 measurement points. In the Spöl, also data along ten cross-sections were sampled in both study sites. This resulted in 100 data points for each Spöl site.

This data sampling is conducted before and after the artificial flood, allowing the comparison the change in habitat diversity caused by the applied measure. To measure at the same locations, cross-sections were measured with a differential GPS. Flow velocity was measured at $40 \%$ of the flow depth in each point with Flowtracker handheld-ADV from SonTek.

\subsection{Artificial floods}

The artificial flood released in the Sarine took 28 hours and had a peak discharge of $195 \mathrm{~m} / \mathrm{s}$ corresponding to a two year flood (Figure 3a). Periods of constant discharge at the increasing limb of the discharge served as calibration measures for discharge measurement. The hydrograph was designed by the dam operator in collaboration with the cantonal authorities, engineering offices and NGOs (Table 1).

The Spöl flood had a peak discharge of $25.9 \mathrm{~m}^{3} / \mathrm{s}$ (Figure 3b). Considering previous studies at the Spöl, the peak discharge corresponds to a flood with a return period of well below one year (Table 1). According to observations of prior to dam construction, the maximum yearly discharge exceeded $40 \mathrm{~m}^{3} / \mathrm{s}$ at a further upstream location and thus is supposed to be even higher at the investigated river sites (Robinson et al., 2018). The largest artificial flood was released in 2009 with a peak discharge of $82 \mathrm{~m}^{3} / \mathrm{s}$ (Kevic et al., 2018).
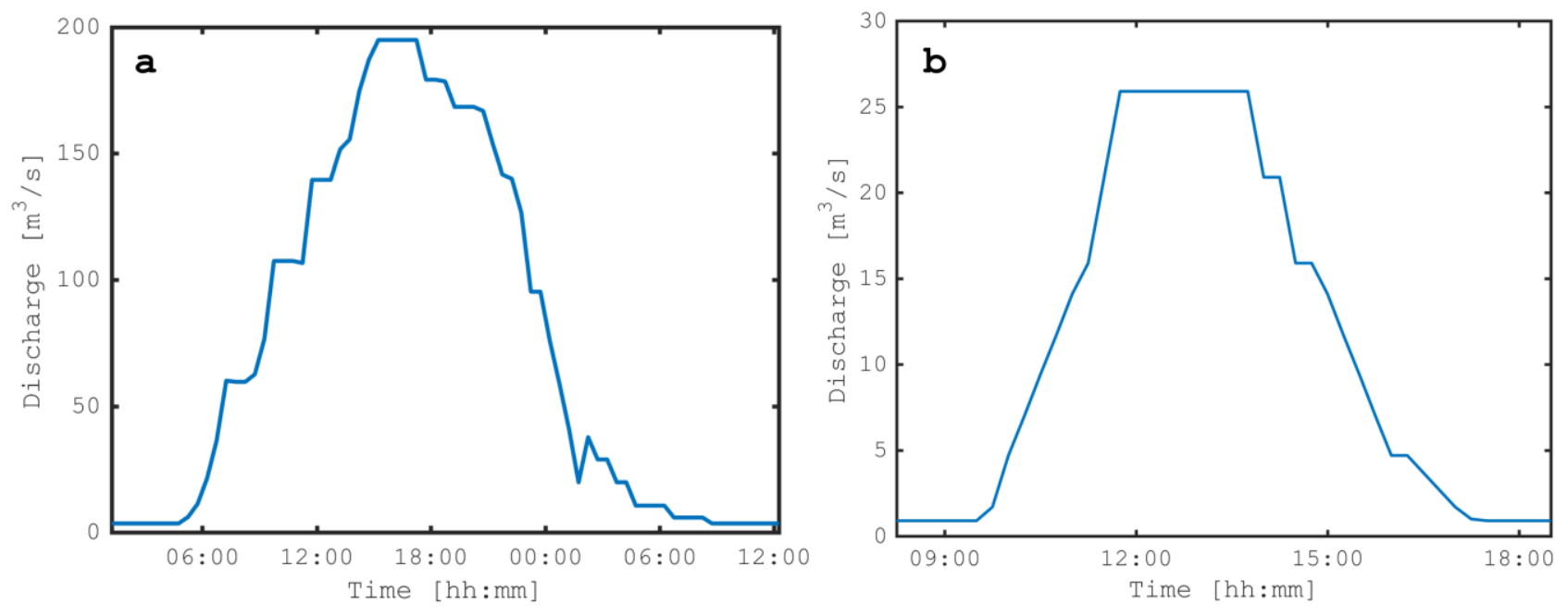

Figure 3. Hydrograph of the artificial flood in the Sarine, released from the Rossens Dam on 14 September 2016 (a) and the atificial flood in the Spöl, released from the Ova Spin Dam on 4 September 2018 (b). Discharge data from Groupe e (Sarine) and Engadiner Kraftwerke AG (Spöl).

\subsection{Sediment availability}

Sediment is almost entirely retained in the Lac de Gruyère. Thus the sediment dynamics in the Sarine segments is highly limited. The artificial flood therefore was combined with sediment replenishment at different locations (Stähly et al., 2018). The sediment was excavated from the adjacent floodplain, allowing tracking of the replenished sediment based on 489 Passive Integrated Transponder (PIT) tags. PIT tags can be recovered with a mobile antenna, allowing the determination of the influence perimeter of the sediment replenishment (Stähly et al., 2019b).

The Lago di Livigno upstream of the Lai dad Ova Spin retains a large amount of the transported sediment in the Spöl. The steep rock exposed gorge walls supply the in the Spöl I study side with sediment and rocks. The confluence with the Ova da Cluozza, $3.2 \mathrm{~km}$ downstream of the Ova Spin Dam brings a large sediment load to the lower part of the Spöl. This difference in sediment availability is observed on-site (see Figure 4). 
Besides the difference in bed slopes, the sediment availability and lateral space cause the creation of different bed forms between the two segments of the Spöl.

Table 1. Characteristics of the flood events at the Sarine and the Spöl. The flow ratio is the ratio between the maximal flood discharge and the maximal residual flow discharge.

\begin{tabular}{lccc}
\hline & & SARINE & SPÖL \\
\hline MAXIMAL FLOOD DISCHARGE & {$\left[\mathrm{m}^{3} / \mathrm{s}\right]$} & 195 & 25.9 \\
ReSIDUAL FLOW DISCHARGE & {$\left[\mathrm{m}^{3} / \mathrm{s}\right]$} & $2.5-3.5$ & $0.55-0.9$ \\
FLOW RATIO & {$[-]$} & 56 & 29 \\
ReLEASED VOLUME & {$\left[\mathrm{Mio} \mathrm{m}^{3}\right]$} & 9.26 & 0.46 \\
DuRATION & {$[\mathrm{hh}: \mathrm{mm}]$} & 28.00 & $07: 30$ \\
\hline
\end{tabular}

\section{RESULTS}

\subsection{Visual observations}

Large geomorphological changes were not visible in both river systems. In the Sarine a change in gravel bars and bed elevation is observed in the perimeter of the sediment replenishment, outside it is absent. The algae on the river bed was removed on the whole residual flow reach.

In the Spöl, the effect differed between the two segments. Over-average snow amounts caused numerous large avalanches in winter 2017/2018, especially in the southern but also the Eastern part of Switzerland. The avalanches transported a large amount of drift wood to the Spöl I. These logs were all transported to the junction with the Ova da Cluozza, where the Spöl widens. Because of the transport of driftwood, more measurements could be taken after the flood event than before. In the downstream segment, topographic changes of the various channels were observed locally. Further, sediment was deposited in the channels, decreasing the maximum flow depth and increasing the wetted surface. Large rocks did not move.

\subsection{Change in habitats}

The HMID was calculated for all studied river segments before and after the flood event (Table 2). The HMID from the Sarine was divided into two sub-segments, based on the recovered tagged stones. From the 277 recovered stones, the maximum transported distance was $286 \mathrm{~m}$ (Figure 5) and the minimum $0 \mathrm{~m}$. Therefore there the segment was cut in a three cross-sections long segment within the replenishment perimeter (HMIDreplenishment) and other HMIDs were calculated based on the remaining six cross-sections (HMID river).

Table 2. HMID values before and after the flood events in the Sarine, the Spöl I and II. The Sarine segment is divided into the impact perimeter of the replenishment (three cross-sections, see Figure 5) and the remaining part of the river (six cross-sections).

\begin{tabular}{|c|c|c|c|c|c|}
\hline & & \multicolumn{2}{|c|}{ HMIDREPLENISHMENT } & \multicolumn{2}{|c|}{ HMIDRIVER } \\
\hline & & BEFORE & AFTER & BEFORE & AFTER \\
\hline \multicolumn{6}{|l|}{ SARINE } \\
\hline DATA POINTS & {$[-]$} & 71 & 58 & 136 & 134 \\
\hline $\mathrm{CVH}_{\mathrm{H}}$ & {$[-]$} & 0.45 & 0.61 & 0.60 & 0.69 \\
\hline CVv & {$[-]$} & 0.62 & 0.74 & 0.88 & 0.92 \\
\hline HMID & & 5.6 & 7.7 & 9.0 & 10.6 \\
\hline Change & & & $+36 \%$ & & $+18 \%$ \\
\hline \multicolumn{6}{|l|}{ SPÖL I } \\
\hline DATA POINTS & {$[-]$} & & & 90 & 107 \\
\hline CVH & {$[-]$} & & & 0.60 & 0.62 \\
\hline CVv & {$[-]$} & & & 0.68 & 0.58 \\
\hline HMID & {$[-]$} & & & 7.2 & 6.4 \\
\hline Change & & & & & $-11 \%$ \\
\hline \multicolumn{6}{|l|}{ SPÖL II } \\
\hline DATA POINTS & {$[-]$} & & & 90 & 104 \\
\hline $\mathrm{CVH}_{\mathrm{H}}$ & {$[-]$} & & & 0.48 & 0.55 \\
\hline CVv & {$[-]$} & & & 0.40 & 0.43 \\
\hline HMID & {$[-]$} & & & 5.3 & 5.7 \\
\hline Change & & & & & $+9 \%$ \\
\hline
\end{tabular}


E-proceedings of the 38th IAHR World Congress

September 1-6, 2019, Panama City, Panama

The HMID increased in both river segments of the Sarine. In the perimeter of the sediment replenishment by $36 \%$, in the residual part of the river by $18 \%$. In the Spöl, the change in HMID is of minor extent. Changes in the range of $10 \%$ can lie within the precision of the measurement. The negative value in the Spöl I reach may be associated with the relatively small return period of the flood which only transported finer material that then settled in previously deeper pools. Another factor for the smaller change may be the fact that in the Spöl, artificial flood events have been applied for several years and the river is approaching a new, dynamic steady state in which a single flood does not increase but sustain the habitat diversity. This is confirmed in various ecological studies performed at the Spöl (Robinson, 2012; Robinson et al., 2018).
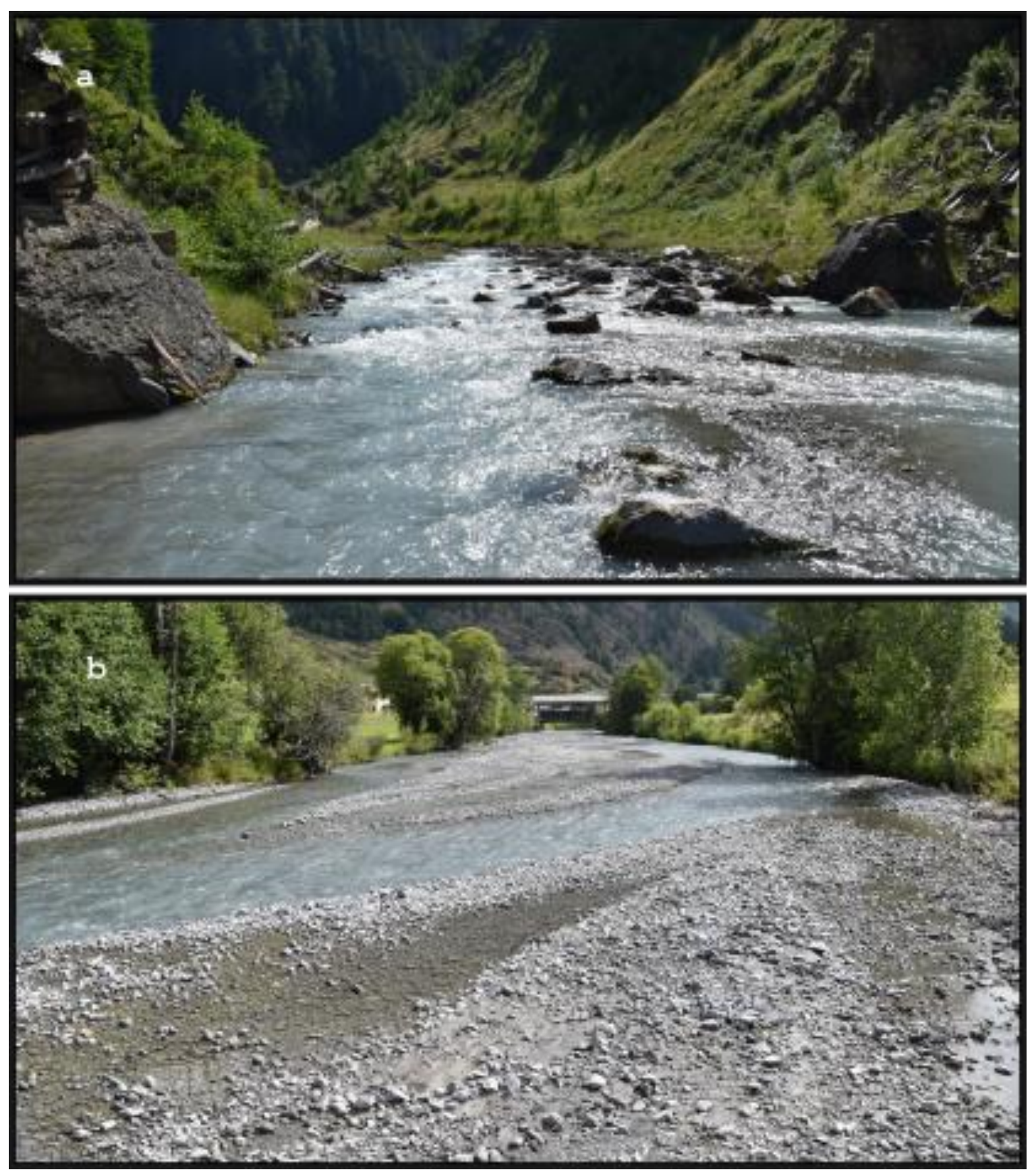

Figure 4. Upstream (a) and downstream (b) segment of the Spöl. Images taken against the flow direction on 18 and 19 July 2018, before the artificial flood; courtesy Severin Stähly 


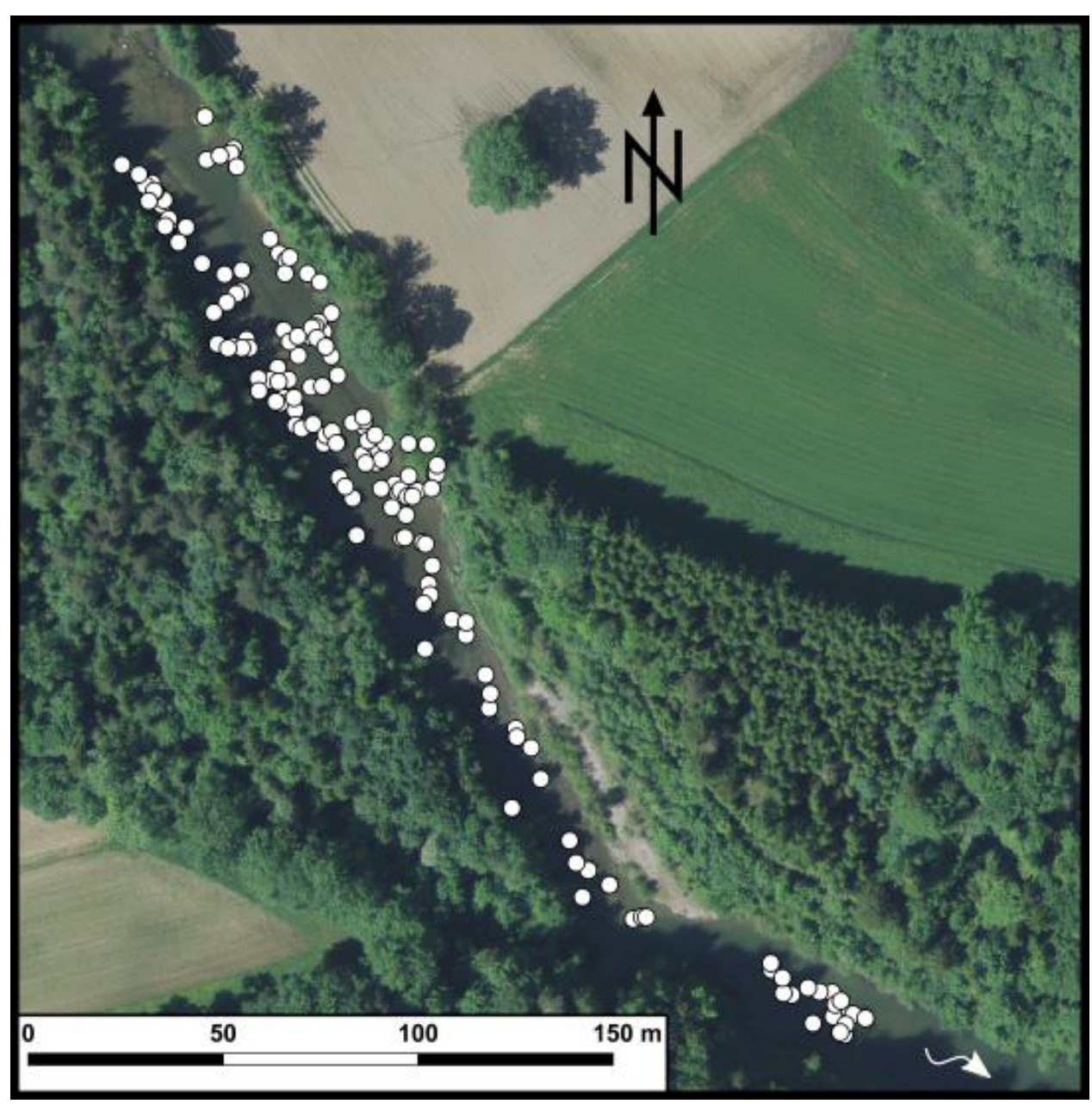

Figure 5. Recovered PIT tag equipped stones in the Sarine. The markers close to the north-west corner of the image did not move. Maximum transported distance was $286 \mathrm{~m}$. Three surveyed cross-sections were located within the perimeter of the recovered PIT tags, the HMID from this reach corresponds to HMIDreplenishment (see Table 2). For the location of the study site, see Figure 1.

\section{CONCLUSIONS}

The case study at the Sarine River in Switzerland revealed that a single artificial flood with a two year return period can increase the hydraulic habitat diversity significantly in a river downstream of a dam with residual flow and without an experienced active flood management for many decades.

If artificial floods are released periodically from a dam as observed at the Spöl, the river downstream may arrive in a new dynamic equilibrium where additional floods do not change the hydraulic variability anymore with a flood of a small magnitude.

A key factor for habitat creation is sediment supply. Geomorphological richness can only be created if sediment is available. If natural sediment sources such as tributaries, land or rock-slides are not present, rivers need to be replenished with sediment if there is an intention to create hydraulic habitats.

If possible, it is most sustainable to use sediment directly from the upstream reservoir (sediment bypass tunnel or dredge). Doing so, long transport distances may be avoided and the grain size distribution corresponds to natural conditions.

Artificial floods and sediment supply are an important measure for a sustainable hydropower and dam management, contributing to the achievement of the United Nations sustainable development goals six and seven, clean water and clean energy.

\section{ACKNOWLEDGEMENTS}

This research project was part of the National Research Programme "Energy Turnaround" (NRP 70, www.nrp70.ch) of the Swiss National Science Foundation (SNSF, Project No. 153972) and the Swiss Federal Office of Energy (SFOE, Project No. 501673-01). Anthony Maître contributed in the framework of his master thesis to the field data collection. Jonas Durand-Gasselin , Elena Battisacco and Diego Tonolla helped during the field campaigns in the Sarine River, Sara Venuleo, Andris Wyss and Christine Schärer in the Spöl River. 
E-proceedings of the 38th IAHR World Congress

September 1-6, 2019, Panama City, Panama 


\section{REFERENCES}

Allan, J.D., \& Castillo, M.M. (2007). Stream ecology: Structure and function of running waters: Second edition. Stream Ecology: Structure and Function of Running Waters: Second Edition. Dordrecht, The Netherlands: Springer. $436 \mathrm{pp}$.

Arnaud, F., Piégay, H., Béal, D., Collery, P., Vaudor, L., \& Rollet, A.J. (2017). Monitoring gravel augmentation in a large regulated river and implications for process-based restoration. Earth Surface Processes and Landforms, 42(13), 2147-2166.

Barbour, M.T., Gerritsen, J., Snyder, B.D., \& Stribling, J. B. (1999). Rapid Bioassessment Protocols for Use in Streams and Wadeable Rivers: Periphyton, Benthic Macroinvertebrates, and Fish - Second Edition. Rapid bioassessment protocols for use in streams and wadeable rivers. EPA- 841-B-99-002. U. S. Environmental Protection Agency. Office of Water. Waschinton, D.C. 35 pp.

Battisacco, E., Franca, M.J., \& Schleiss, A.J. (2016). Sediment replenishment: Influence of the geometrical configuration on the morphological evolution of channel-bed. Water Resources Research, 52(11), 88798894.

Döring, M., Tonolla, D., Robinson, C.T., Schleiss, A.J., Stähly, S., Gufler, C., ... Di Cugno, N. (2018). Künstliches Hochwasser an der Saane - Eine Massnahme zum nachhaltigen Auenmanagement [in german]. Wasser Energie Luft, 2, 119-127.

Feio, M.J., Calapez, A.R., Elias, C.L., Cortes, R.M.V., Graça, M.A.S., Pinto, P., \& Almeida, S.F.P. (2016). The paradox of expert judgment in rivers ecological monitoring. Journal of Environmental Management, 184, $609-616$.

Gaeuman, D. (2012). Mitigating Downstream Effects of Dams. In M. Church, P. M. Biron, \& A. G. Roy (Eds.), Gravel-Bed Rivers: Processes, Tools, Environments. John Wiley \& Sons Ltd. 182-189.

Gaeuman, D., Stewart, R., Schmandt, B., \& Pryor, C. (2017). Geomorphic response to gravel augmentation and high-flow dam release in the Trinity River, California. Earth Surface Processes and Landforms, 42(15), 2523-2540.

Gostner, W., Alp, M., Schleiss, A.J., \& Robinson, C.T. (2013). The hydro-morphological index of diversity: A tool for describing habitat heterogeneity in river engineering projects. Hydrobiologia, 712(1), 43-60.

Heckmann, T., Haas, F., Abel, J., Rimböck, A., \& Becht, M. (2017). Feeding the hungry river: Fluvial morphodynamics and the entrainment of artificially inserted sediment at the dammed river Isar, Eastern Alps, Germany. Geomorphology, 291, 128-142.

Heggenes, J. (1996). Habitat selection by brown trout (Salmo trutta) and young Atlantic salmon (S-salar) in streams: Static and dynamic hydraulic modelling. Regulated Rivers-Research \& Management, 12(July 1994), 155-169.

Kevic, M., Ortlepp, J., Mürle, U., \& Robinson, C. T. (2018). Effects of experimental floods in two rivers with contrasting valley morphologies. Fundamental and Applied Limnology / Archiv Für Hydrobiologie, 192(1), 145-160.

Kondolf, G.M. (1997). HungryWater: Effects of Dams and Gravel Mining on River Channels. Environmental Management , 21(4), 533-551.

Moyle, P.B., \& Mount, J.F. (2007). Homogenous rivers, homogenous faunas. Proceedings of the National Academy of Sciences, 104(14), 5711-5712.

Petts, G.E., \& Gurnell, A.M. (2005). Dams and geomorphology: Research progress and future directions. Geomorphology, 71(1-2), 27-47.

Rinaldi, M., Belletti, B., Bussettini, M., Comiti, F., Golfieri, B., Lastoria, B., ... Surian, N. (2017). New tools for the hydromorphological assessment and monitoring of European streams. Journal of Environmental Management, 202, 363-378.

Robinson, C.T. (2012). Long-term changes in community assembly, resistance, and resilience following experimental floods. Ecological Applications : A Publication of the Ecological Society of America, 22(7), 1949-1961.

Robinson, C.T., Siebers, A.R., \& Ortlepp, J. (2018). Long-term ecological responses of the River Spöl to experimental floods. Freshwater Science, 433-447.

Staentzel, C., Arnaud, F., Combroux, I., Schmitt, L., Trémolières, M., Grac, C., ... Beisel, J.N. (2018). How do instream flow increase and gravel augmentation impact biological communities in large rivers: A case study on the Upper Rhine River. River Research and Applications, 34(2), 153-164.

Stähly, S., Franca, M.J., Robinson, C.T., \& Schleiss, A.J. (2019). Sediment replenishment combined with an artificial flood improves river habitats downstream of a dam. Scientific Reports, 9(1), 5176.

Stähly, S., Gostner, W., Franca, M.J., Robinson, C.T., \& Schleiss, A.J. (2019). Sampling sufficiency for determining hydraulic habitat diversity. Journal of Ecohydraulics.

Stähly, S., Maître, A., Franca, M.J., Robinson, C.T., \& Schleiss, A.J. (2018). Experiments with sediment replenishment in a residual flow reach: Comparison of field data with laboratory experiments. In A. Paquier \& N. Rivière (Eds.), 9th International Conference on Fluvial Hydraulics River Flow 2018, p. 2022.

Statzner, B., Gore, J.A., \& Resh, V. H. (1988). Hydraulic Stream Ecology: Observed Patterns and Potential Applications. Journal of the North American Benthological Society, 7(4), 307-360. 
Wohl, E., Bledsoe, B. ., Jacobson, R.B., Poff, N.L., Rathburn, S.L., Walters, D.M., \& Wilcox, A.C. (2015). The natural sediment regime in rivers: Broadening the foundation for ecosystem management. BioScience, 65(4), 358-371. 